\title{
An evaluation of gillnet CPUE as an index of perch density in small forest lakes
}

\section{Olin, Mikko Johannes}

2016-01

Olin , M J , Tiainen , J M , Kurkilahti , M , Rask , M \& Lehtonen , H V T 2016 , ' An evaluation of gillnet CPUE as an index of perch density in small forest lakes ', Fisheries Research, vol. 173 , no. 1 , pp. 20-25. https://doi.org/10.1016/j.fishres.2015.05.018

http://hdl.handle.net/10138/161340

https://doi.org/10.1016/j.fishres.2015.05.018

Downloaded from Helda, University of Helsinki institutional repository.

This is an electronic reprint of the original article.

This reprint may differ from the original in pagination and typographic detail.

Please cite the original version. 


\title{
An evaluation of gillnet CPUE as an index of perch density in small forest lakes
}

\author{
M. Olin ${ }^{\mathrm{a}, *}$, J. Tiainen ${ }^{\mathrm{a}}$, M. Kurkilahti ${ }^{\mathrm{b}}$, M. Rask ${ }^{\mathrm{c}}$, H. Lehtonen ${ }^{\mathrm{a}}$ \\ a University of Helsinki, Department of Environmental Sciences, PO Box 65, FIN-00014 Helsinki, Finland \\ b Finnish Game and Fisheries Research Institute, Itäinen Pitkäkatu 3, FIN-20520 Turku, Finland

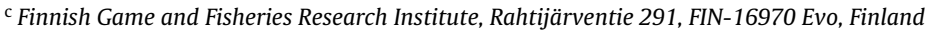

\section{A R T I C L E I N F O}

\section{Article history:}

Received 13 November 2014

Received in revised form 4 May 2015

Accepted 15 May 2015

Available online $\mathrm{xxx}$

\section{Keywords:}

Gillnet catchability

Mark and recapture

Density

Temperature

Water colour

Oxygen

\begin{abstract}
A B S T R A C T
Gillnets are commonly used for monitoring fish communities and assessing the ecological quality in European lakes. However, the relationship between gillnet CPUE and fish abundance is not linear and depends on several factors affecting the catchability of gillnets. We investigated the effects of high water colour, naturally anoxic hypolimnion, water temperature and sex ratio on the catchability of perch Perca fluviatilis in gillnets. Data were collected during 10 years in nine forest lakes in southern Finland. Such lakes are very common in Finland. The density and size structure of perch populations were estimated by mark and recapture method during spring and standard gillnet fishing (CEN, 2005. Water quality Sampling of Fish with Multimesh Gillnets. European Committee for Standardization, Brussels (EN 14757)) in late summer. Perch CPUE was positively but non-linearly dependent on the perch density. Catchability increased with water colour, water temperature, and the volume of the anoxic hypolimnion. The sex ratio was also important because late summer gillnetting overestimates the proportion of female perch. If the factors that affect the catchability of perch in gillnets are taken into account, gillnet CPUE using standard methods can be used as rough index of fish density in small forest lakes.
\end{abstract}

(c) 2015 Elsevier B.V. All rights reserved.

\section{Introduction}

Gillnet catch per unit effort (CPUE) is a vague index of fish density. In many studies, positive but non-linear relationship between gillnet CPUE and estimated fish density has been found indicating decreasing catchability with increasing fish density (Borgstrøm, 1992; Enderlein and Appelberg, 1992; Hansson and Rudstam, 1995; Linløkken and Haugen, 2006; Olin et al., 2009). Contradictory, some studies reported no dependence (Enderlein and Appelberg, 1992; Peltonen et al., 1999; Sutela et al., 2008) or even negative dependence of gillnet CPUE on fish density (Linløkken and Haugen, 2006; Harley et al., 2001). The latter results can be explained by very low fish activity in high fish densities, a phenomenon called "hyperstability" (Harley et al., 2001). In previous studies, the factors affecting the relationship between gillnet CPUE and fish density included species and size distribution, gear properties, sampled habitat, environmental conditions, and fish density and behaviour. The dependence of gillnet CPUE on density relies on catchability, which is affected by the probabilities of encountering (PE),

\footnotetext{
* Corresponding author. Tel.: +358 504486452.

E-mail address: mikko.olin@helsinki.fi (M. Olin).
}

contacting (PCo) and retaining (PR) by the net (Hamley, 1975; Kurkilahti, 1999). PE is dependent on numerous factors that affect the average distance fish swim (e.g. fish abundance, fish size, temperature, food resources and species interactions). PCo is affected by fish size in relation to mesh size, fish morphology, fish ability to avoid the net and gillnet saturation (Olin et al., 2004). Fish ability to escape from the net determines PR (Prchalová et al., 2011).

As gillnets are relatively easy and inexpensive to use even in challenging environments and with the completion of CEN (2005) standard, numerous research programmes use gillnets in monitoring changes in relative fish abundance, community structure and size distribution (Argillier et al., 2012, and the references therein). In Finland, standard gillnet monitoring is used nation-wide to follow the changes in the ecological status of lakes according to Water Framework Directive, because the assessment method is based on the gillnet results (Olin et al., 2013). A large part of the Finnish lakes are small and humic (Eloranta, 2004). The characteristics of these lakes are low visibility, high summer temperature, strong stratification, and anoxic hypolimnion. All the previous factors affect fish activity and behaviour and thus their catchability by gillnets (Hamley, 1975). It is not known how high water colour and low volume of oxygenated water affect the catchability of perch in gillnets. 
The aim of this study was to explore how high humic concentration (low visibility) and anoxic hypolimnion (reduced viable habitat) affect perch catchability in gillnets thus changing the relationship between fish density and gillnet CPUE. We used perch (Perca fluviatilis) as target species because it is very common in all kind of lakes in Finland (Tonn et al., 1990), and its density is relatively easy to estimate in small lakes (Linløkken and Haugen, 2006; Rask et al., 2014). We hypothesized that low visibility can either decrease the catchability of perch in gillnets due to decreased activity, or increase the catchability because perch are less able to avoid the net using visual cues. We also hypothesize that low volume of oxygenated water should increase perch catchability since fish should concentrate in the water volume with adequate oxygen levels and therefore the density of fish around the nets set in that area would be higher than expected from the lake wide average density. We also investigated the effect of water temperature on perch catchability, because water temperature should increase fish activity and thus catchability in gillnets (Hansson and Rudstam, 1995; Linløkken and Haugen, 2006).

\section{Material and methods}

\subsection{Study lakes and water samples}

The study lakes included nine small forest lakes with varying area, depth and water quality (Table 1). The water quality was monitored during the gillnetting days except for water colour which was measured during autumn turnover. The annual lake-specific average values of temperature ( $1 \mathrm{~m}$ depth), water colour, Secchi depth and oxygen concentration ( $2 \mathrm{~m}$ depth) ranged between $13.5-23.7^{\circ} \mathrm{C}$ (average 19.5), $40-557 \mathrm{mg} \mathrm{Ptl}^{-1}$ (average 210), 0.48-3.22 $\mathrm{m}$ (average 1.53) and 0.5-13.7 $\mathrm{mg} \mathrm{l}^{-1}$ (average 5.8), respectively. We used oxygen concentration in $2 \mathrm{~m}$ depth as an index of the volume of oxygenated water (Rask et al., 2014). The epilimnion in these brown water lakes is usually $2 \mathrm{~m}$ thick (Salonen et al., 1984), and the oxygen concentration in this depth is a reliable indicator of the oxygen conditions. In some lakes and years oxygen was depleted in mid-summer already in $2 \mathrm{~m}$ depth whereas in other lakes whole water volume was oxygenated throughout the summer in every year. The fish communities in the lakes were dominated by roach (Rutilus rutilus), perch and pike (Esox lucius), except the lakes Valkea-Kotinen and Iso Valkjärvi that had no roach population (Olin et al., 2010).

\subsection{Sampling of fish}

The perch population densities were estimated in spring by mark and recapture method and the relative densities in late summer by standard gillnetting method (extended CEN standard, see Olin et al., 2013) during 2004-2013. As perch density was estimated only once a year, the gillnet and water quality results were combined for each year, and the data included 60 lake-years.

The gillnetting followed stratified random sampling procedure with depth zones of $<3 \mathrm{~m}$ and $>3 \mathrm{~m}$, and randomized gillnet sites. We used Nordic gillnets (height $1.5 \mathrm{~m}$, length $30 \mathrm{~m}$, area $45 \mathrm{~m}^{2}$ ) with 12 mesh sizes between 5 and $55 \mathrm{~mm}$ from knot to knot (Olin et al., 2013). In the shallower zone, only bottom gillnets were used. In the deeper zone, gillnets were set both at surface and on the bottom. However, no gillnets were set on anoxic bottom, because perch can't survive when oxygen concentration is below $2.25 \mathrm{mgl}^{-1}$ in warm water $\left(20-26^{\circ} \mathrm{C}\right.$, Thorpe, 1977). In each year, gillnetting was conducted three times fortnightly (mid-July, end of July and midAugust), except for the Lakes Valkea-Kotinen and Halsjärvi, which were sampled only twice in July-September (2-9 week interval). Gillnets were set in the evening (appr. 20:00) and hauled in the next morning (appr. 08:00), thus the fishing time was ca. $12 \mathrm{~h}$. The total fishing effort ranged from 6 to 21 gillnet nights per year depending on the lake size and depth (Table 2). Each gillnet was handled separately and fish were sorted into species, counted, weighed and measured for total length. Subsamples of 98-389 perch with known total length were sexed in each lake. Based on the data of these subsamples, the rest of the perch were sexed according to lake-specific length-sex-models, where the probability of fish to be female increased with fish length according to 2 nd degree polynomial equation: probability to be female $=a^{*}$ length ${ }^{2}+b^{*}$ length $+c$, until the probability reaches (1). For perch in the subsamples, age and annual length increments were estimated (otoliths and opercular bones, Monastyrsky's procedure, Bagenal and Tesch, 1978).

Perch marking and recapturing was conducted in spring during spawning (within 2-3 weeks after ice-break) by using Schnabel multiple marking method (Seber, 1982). Fish were caught by wire traps and marked by fin-clipping (tip of the left or right pelvic fin depending on the year; Horppila et al., 2010). Perch were measured for length ( $1 \mathrm{~cm}$ size classes) and sexed according to running milt or swollen abdomen and genital pore. The fishing was continued until the $95 \%$ confidence limits were below $20 \%$ of the total density estimates. The number of yearly marked and recaptured perch ranged between 282-6148 and 81-1563, respectively (Table 2).

\subsection{Increasing the comparability between perch density and CPUE estimates}

Because of different sampling season and selectivity, wire trap and gillnet catch differed in sex ratio, size distribution and species composition. Furthermore, fish mortality and growth from spring to late summer had to be taken into account.

The perch catch in spring was dominated by males (average share of females was only 19\%) due to their higher spawning activity (Craig, 2000). In late summer gillnet catch, females were more abundant than males (average share of females 68\%) as they are more active during growing season because of higher energy demand (Henderson et al., 2000). For the mark and recapture catch, the sex ratio was made more equal by adding up the separate estimates for males and females. Still, the average female density estimate was only 0.65 of the average male estimate. To take into account the female-biased sex-ratio in gillnet catch, the estimated sex ratio (female/male) was included in the statistical model (see further). The annual lake-specific sex ratios in gillnet catch ranged from 1.1 to 5.4 (average 2.4).

As the smallest mesh sizes in Nordic gillnets are 5, 6.25 and $8 \mathrm{~mm}$, gillnets also caught juvenile perch that had to be excluded for comparability. Furthermore, the adult perch included in the density estimates, of which the smallest were $7 \mathrm{~cm}$ long (total length), grew from spring to late summer (average length increment $2 \mathrm{~cm}$ ). To take these aspects into account we excluded smaller than $9 \mathrm{~cm}$ perch from the gillnet catch.

To acknowledge the mortality from spring to late summer, we estimated annual instantaneous total mortality rate $(Z)$ from the age-distribution by the catch curve method (Robson and Chapman, 1961). Lake and year specific age-length keys were used to transform length distribution of gillnet catch into age distribution where the log-regression model was fitted. We assumed that the annual $Z$ could be used as a proxy of the mortality also on shorter time period from spring to late summer. The annual lake-specific $Z$ ranged from 0.06 to 0.43 (average 0.18 ).

Gillnets also caught fish other than perch (mainly roach), and the catch of other species may have affected the catchability of perch. Thus, the catch of other species was included in the statistical model (see further). The annual lake-specific CPUE of the other species

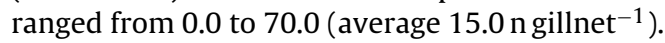


Table 1

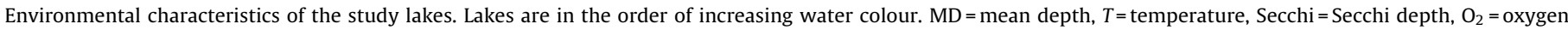

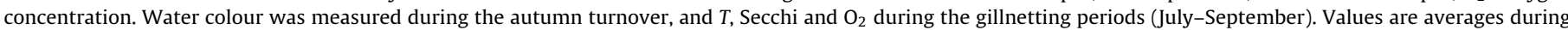
the sampling years.

\begin{tabular}{|c|c|c|c|c|c|c|c|}
\hline Lake & Sampling years & Area (ha) & $\mathrm{MD}(\mathrm{m})$ & Colour (mg Pt l-1) & $T(1 \mathrm{~m})$ & $\operatorname{Secchi}(\mathrm{m})$ & $\mathrm{O}_{2}\left(\mathrm{mg} \mathrm{l}^{-1}, 2 \mathrm{~m}\right)$ \\
\hline Iso Valkjärvi, E & 2007-2012 & 1.57 & 6 & 49 & 20.8 & 2.96 & 9.3 \\
\hline Iso Valkjärvi, W & 2007-2012 & 2.21 & 8 & 79 & 21.4 & 2.56 & 9.3 \\
\hline Hokajärvi & 2006-2013 & 8.42 & 6 & 157 & 20.1 & 1.52 & 5.6 \\
\hline Haarajärvi & 2006-2013 & 13.83 & 12 & 165 & 20.2 & 1.55 & 8.2 \\
\hline Valkea-Kotinen & 2004-2013 & 3.59 & 6 & 172 & 17.6 & 1.43 & 5.1 \\
\hline Halsjärvi & 2004-2007 & 3.11 & 6 & 182 & 17.2 & 1.41 & 4.8 \\
\hline Iso Mustajärvi & 2011, 2013 & 2.46 & 6 & 242 & 20.5 & 1.08 & 1.8 \\
\hline Majajärvi & 2006-2013 & 3.38 & 12 & 365 & 20.2 & 0.89 & 3.5 \\
\hline Haukijärvi & 2006-2013 & 2.06 & 8 & 428 & 18.7 & 0.80 & 3.4 \\
\hline
\end{tabular}

Table 2

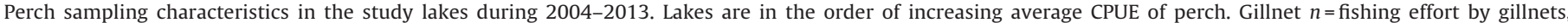

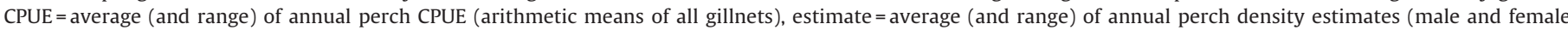
estimates combined), marked = range of number of yearly marked perch, recaptured = range of $n$ of all yearly recaptured perch.

\begin{tabular}{|c|c|c|c|c|c|c|}
\hline Lake & Sampling years & Gillnet (n) & CPUE (n gillnet ${ }^{-1}$ ) & Estimate $\left(\mathrm{nha}^{-1}\right)$ & Marked (n) & Recaptured (n) \\
\hline Iso Mustajärvi & 2011, 2013 & 8 & $4.2(1.5-7.9)$ & $491(439-544)$ & $441-448$ & $112-117$ \\
\hline Halsjärvi & 2004-2007 & 8 & $4.3(1.0-6.3)$ & $1151(624-1830)$ & $550-742$ & $125-236$ \\
\hline Haukijärvi & 2006-2013 & $6-8$ & $5.4(1.0-10.7)$ & $820(311-1133)$ & $389-1167$ & $108-345$ \\
\hline Hokajärvi & 2006-2013 & 15 & $6.4(2.9-11.0)$ & $487(367-679)$ & 1114-1960 & $275-723$ \\
\hline Majajärvi & 2006-2013 & 9 & $7.7(1.6-15.1)$ & $2655(736-3848)$ & $954-2815$ & $97-577$ \\
\hline Haarajärvi & 2006-2013 & 21 & $8.1(3.7-14.3)$ & $969(428-1635)$ & $1880-6148$ & $208-1563$ \\
\hline Valkea-Kotinen & 2004-2013 & 8 & $8.5(4.6-12.3)$ & $3593(2176-5662)$ & $763-2128$ & $81-430$ \\
\hline Iso Valkjärvi, W & 2007-2012 & $6-8$ & $9.6(2.3-18.2)$ & $1154(116-3882)$ & $282-1651$ & $83-234$ \\
\hline Iso Valkjärvi, E & 2007-2012 & $6-8$ & $9.9(4.1-14.5)$ & $1046(126-2889)$ & $479-1754$ & $139-466$ \\
\hline
\end{tabular}

\subsection{Statistical analyses}

We fitted the following linear mixed model with repeated measures to assess how density and other factors affect the catch per unit effort of perch in gill nets (CPUE).

In (CPUE) $=\alpha_{0}+\beta_{1} \times$ Indensity $+\beta_{2} \times$ Temperature $+\beta_{3} \times$ Secchi depth $+\beta_{4} \times$

Oxygen concentration $+\beta_{5} \times$ Mortality $+\beta_{6} \times$ Sex ratio $+\beta_{7} \times$

InCPUE of other species $+\alpha_{1} \times$ Year (Lake) $+e$

The response variable, gillnet CPUE of perch was natural logarithm transformed to ensure normal distribution (Kurkilahti, 1999). The independent variables were In perch density, water temperature ( $1 \mathrm{~m}$ depth), Secchi depth, oxygen concentration in $2 \mathrm{~m}$ depth, mortality and sex ratio (female/male in gillnet catch). Density was ln-transformed to ensure linear relationship between In-transformed gillnet CPUE and fish density in the model. All other fixed effects than density were average values during gillnetting or calculated from the gillnet catch (mortality and sex ratio). Secchi depth was used as a proxy of water colour since water colour was not measured during the gillnetting days. In another data set where Secchi depth and water colour were collected simultaneously, the correlation between water colour and Secchi depth was high and significant $\left(r_{S}=-0.765, P<0.001, n=326\right)$. We also took into account the random effects of the study lake and the sampling year. Random variable was year nested in lake (R-side structure ARH(1)), so the repeated measures within the lake were included in the model. We used stepwise procedure for reducing the model starting from 3-level interaction model and best model was chosen according to corrected Akaike's information criteria (AICC).

\section{Results}

According to the best mixed linear model, perch gillnet CPUE was clearly dependent on perch density (Table 3). However, the dependence was not linear (in arithmetic scale) and catchability decreased with fish density (Fig. 1). Furthermore, besides density,
Table 3

Best mixed linear model with repeated measurements predicting perch gillnet CPUE from estimated perch density, Secchi depth, water temperature (1 $\mathrm{m}$ depth), oxygen concentration ( $2 \mathrm{~m}$ depth) and sex ratio (in gillnet catch)

\begin{tabular}{lrlrrr}
\hline Effect & Estimate & SE & \multicolumn{1}{l}{ DF } & $F$ value & $P$ value \\
\hline Intercept & -5.971 & 0.824 & 11.810 & & $<0.001$ \\
In density & 0.282 & 0.039 & 12.700 & 51.83 & $<0.001$ \\
Secchi depth & 0.208 & 0.058 & 6.909 & 12.79 & 0.009 \\
Temperature & 3.157 & 0.334 & 8.577 & 89.08 & $<0.001$ \\
Oxygen & 8.799 & 1.236 & 7.307 & 50.66 & $<0.001$ \\
Sex ratio & -0.230 & 0.020 & 4.873 & 128.31 & $<0.001$ \\
Temperature $\times$ oxygen & -4.939 & 0.648 & 7.183 & 58.04 & $<0.001$ \\
\hline
\end{tabular}

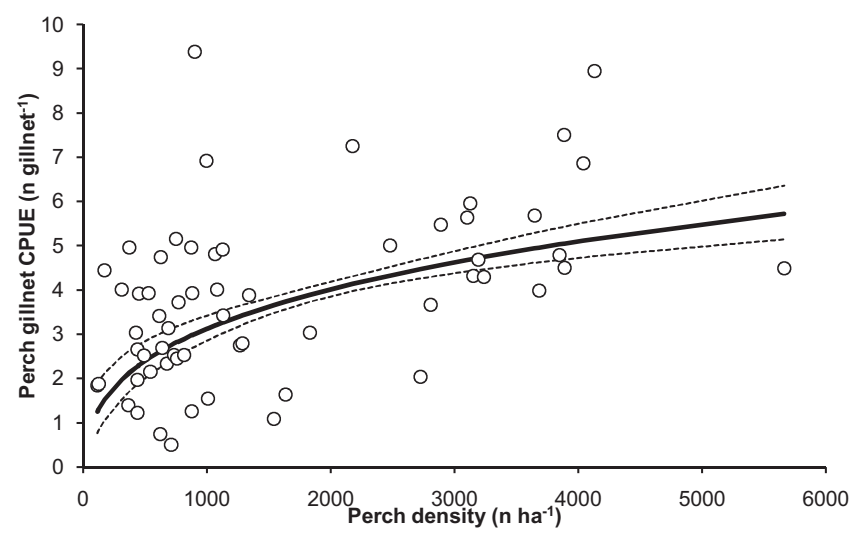

Fig. 1. Observed gillnet CPUE vs. density values (open circles), and fitted values (black line) with 95\% confidence limits (dotted lines) of the best model (Table 3) when other explanatory factors (Secchi depth, temperature and oxygen concentration) were assigned their average values. Gillnet CPUEs are geometric averages (back-transformed from the average of ln-transformed CPUE data).

CPUE was statistically significantly affected by water transparency, temperature, volume of oxygenated water and sex ratio in the gillnet catch (Table 3). The effects of mortality and the CPUE of other species were statistically insignificant and were excluded during 


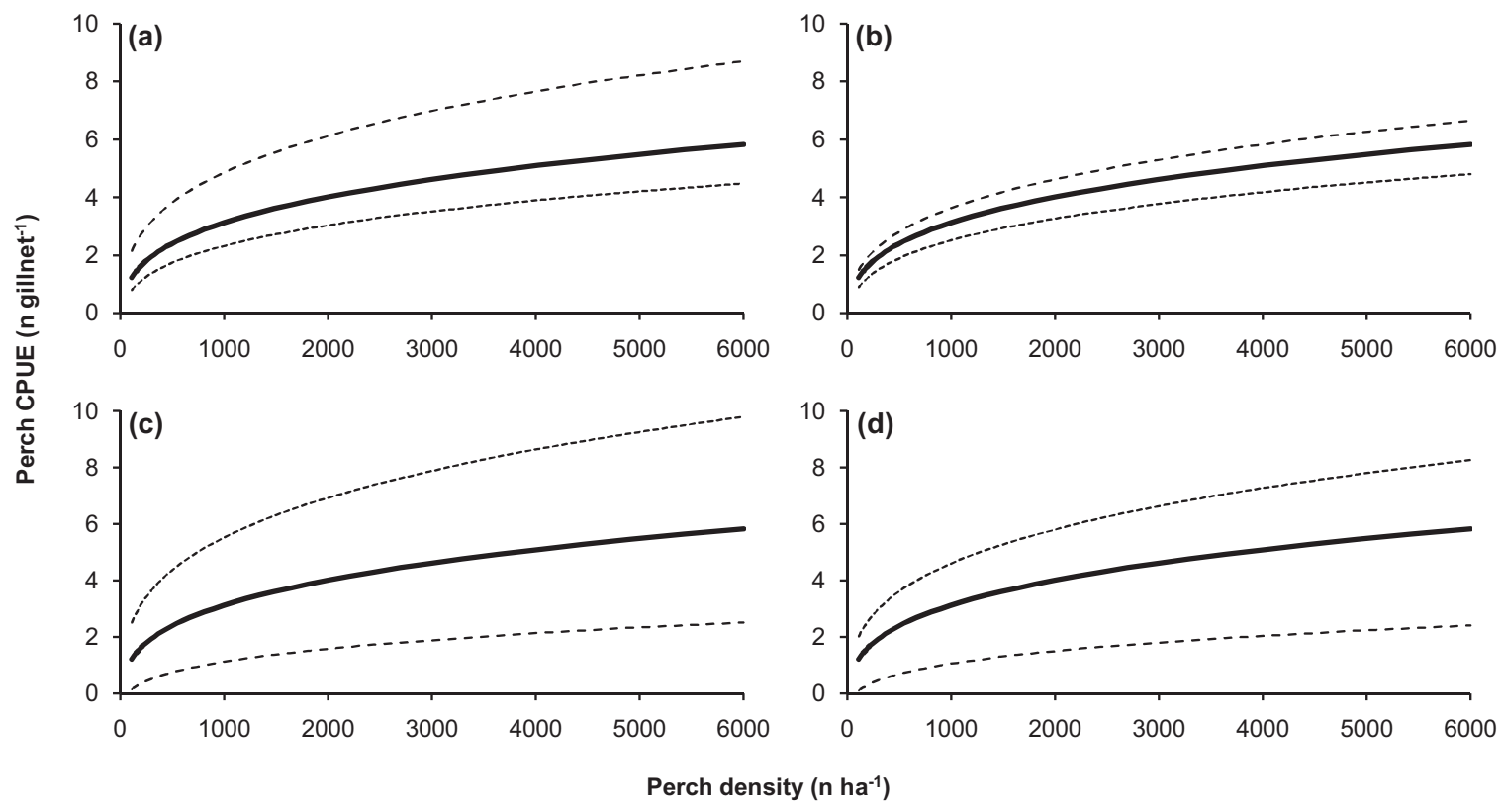

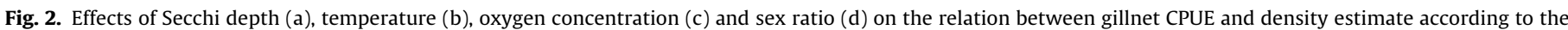
best model (Table 3). The gillnet CPUEs at the minimum (dotted), average (black line) and maximum (dashed) value of each factor are shown.

the model reduction, which increased the model fit according to AICC.

When considering the other factors that affected the gillnet catchability, Secchi depth had a positive effect on the perch CPUE in relation to perch density (Fig. 2). In other words, certain perch density resulted to higher CPUE in clear than in dark water. On average on the density gradient, CPUE gave $31 \%$ higher density index when Secchi depth increased by $1 \mathrm{~m}$. The difference in the CPUEs when the Secchi depth had the highest and lowest observed value (3.2 and $0.5 \mathrm{~m}$, respectively) was on average 2.1 -fold.

As expected, water temperature increased gillnet catchability (Fig. 2), causing on average $20 \%$ higher CPUE with $5{ }^{\circ} \mathrm{C}$ temperature rise at a given density. When the temperature had the highest observed value $\left(23.7^{\circ} \mathrm{C}\right)$, the CPUE was on average 1.4 times higher compared to the coldest situation (water temperature $13.5^{\circ} \mathrm{C}$ ).

Thin oxygenated water layer, as hypothesized, gave higher perch CPUE in relation to density compared to better oxygen conditions. The effect of oxygen was remarkable in this data set. At a given perch density, CPUE increased on average $11 \%$ with $1 \mathrm{mgl}^{-1}$ reduction in $\mathrm{O}_{2}$ concentration in $2 \mathrm{~m}$ depth. The difference in the CPUEs when the oxygen concentration had the observed highest and lowest value (13.7 and $0.5 \mathrm{mg} \mathrm{l}^{-1}$, respectively) was on average 5.0 -fold. The effects of temperature and oxygen showed interaction (Table 3). Low oxygen conditions increased the effect of water temperature, and the highest CPUE in relation to density was reached when oxygenated water layer was thin and water temperature was high. In high oxygen conditions, the effect of water temperature in the model was reversed, and, at a given perch density, cold water resulted in higher CPUE than warm water. The latter model result was likely an artefact since no such conditions, high oxygen concentration and low water temperature, existed in this data set.

When the sex ratio (female/male in gillnet catch) increased, the catchability of gillnets decreased (Fig. 2). This was probably due to the observed negative correlation $\left(r_{s}=-0.318, P=0.014\right)$ between perch CPUE and the sex ratio, resulting in high male proportion when CPUE was high. In the gillnet catch, perch CPUE, mean size and sex ratio interacted, so that CPUE was, though not statistically significantly, inversely proportional to mean size $\left(r_{s}=-0.139, P=0.293\right)$, and mean size correlated negatively with sex ratio $\left(r_{s}=-0.781, P<0.001\right)$ indicating high male proportion when the mean size was small and CPUE was high.

\section{Discussion}

The gillnet CPUE of perch was dependent on the perch density in lakes with high humic concentration and possibly anoxic hypolimnion. However, the density-dependence was not linear and was affected by water clarity, temperature and the volume of oxygenated epiliminion. The sex ratio in gillnet catch had to be considered, since late-summer gillnet sampling gave female-biased estimates.

Perch CPUE was non-linearly dependent on density and CPUEindex gave higher underestimation of the real abundance when fish density increased. This decreasing catchability with increasing fish density has been observed in many earlier studies and can be due to several factors (Borgstrøm, 1992; Enderlein and Appelberg, 1992; Hansson and Rudstam, 1995; Linløkken and Haugen, 2006; Olin et al., 2009). In this study, the gear saturation (Minns and Hurley, 1988) probably has not affected much on the decreased catchability, as the accumulation percent (proportion of occupied meshes) even in the mesh sizes with the highest catch rates $\left(10,12.5\right.$ and $15.5 \mathrm{~mm}, \mathrm{CPUE} \mathrm{m}^{-2} \pm \mathrm{SD}=2.47 \pm 3.34,2.20 \pm 2.12$ and $1.15 \pm 1.25$, respectively) was below the threshold $0.16 \%$ in $\geq 90 \%$ of the observations. The threshold represents the point where the accumulation-related reduction in catchability is starting to be considerable ( $\geq 20 \%$ ) in lakes with low visibility (Olin et al., 2004). Furthermore, according to Prchalová et al. (2011) the effects of saturation is quite insignificant when catch is below $3 \mathrm{~kg}$ per standardized gillnet, and only 2 gillnets out of 709 reached the catch of $3 \mathrm{~kg}$ in our data set. Visual avoidance (Olin et al., 2004) is also unlikely since the catch-level was low and visibility in the lakes was poor due to brown water. No sliming and thus reduced catchability of gillnets was observed. Reduced activity or changed behaviour in high fish densities (Borgstrøm, 1992; Linløkken and Haugen, 2006) is the most likely reason for reduced catchability, since fish densities in the viable habitats during low volume of oxygenated water are probably rather high. In high fish densities, fish activity and swimming speed can be reduced because of declined prey density or changes in prey type or foraging habitats. Contrary to the 
findings of Linløkken and Haugen (2006), we did not find negative correlation between perch density and gillnet CPUE in high perch densities though the densities in this study were much higher (maximum density estimate $5662 \mathrm{n} \mathrm{ha}^{-1}$ ) than in their study (maximum density of $1064 \mathrm{nha}^{-1}$ ). The probable reason for this is the wider density gradient and the inclusion of Secchi depth in the model in our study.

Low water colour resulted in relatively high abundance index of CPUE. This is probably due to higher activity and thus catchability of perch in better visual conditions (Estlander et al., 2012). The hypothesis of lower catchability in clearer water because of better ability of fish to avoid the net by visual cues was thus not supported by the results, and the water clarity effect on fish activity seems to be higher than the effect of visual avoidance in this data (Hansson and Rudstam, 1995; Olin et al., 2004). As stated in the previous paragraph, the water transparency and catch levels were probably too low to enable visual avoidance.

The hypothesis that assumed poor oxygen conditions lead up to higher catchability of fish and thus increased density-dependence of gillnet CPUE was clearly supported by the results. When the volume of oxygenated water is small, fish are concentrated in smaller water volume (Ruuhijärvi et al., 2010), which decreases the average distance to the nearest gillnet and thus increases PE. This result could not be compared to other results as we found no literature concerning this issue. We avoided setting gillnets in anoxic hypolimnion as we had current information of the oxygen profile in the study lakes. During the gillnet monitoring according the standard (CEN, 2005), gillnets can be placed also in anoxic hypolimnion. In this case, the CPUE of depth strata in anoxic habitats are estimated to be 0 , and the total gillnet CPUE can be a downward-biased density index compared to corresponding lakes with no oxygen problems. On the other hand, if fish are concentrated in oxygenated habitats and only these areas are sampled, the gillnet CPUE can be overestimated. To see how following the standard CEN sampling would have changed the results, we ran a similar model (Table 3) with the average gillnet CPUEs including assumed zero catches in anoxic depth zones. Naturally, the average gillnet CPUEs were much lower (on average 26\%) but also the effect of oxygen was clearly diminished and was on average $6 \%$ with $1 \mathrm{mg} \mathrm{l}^{-1}$ reduction in $\mathrm{O}_{2}$ concentration compared to $11 \%$ before the inclusion of zero catches. However, the low oxygen conditions still significantly $(P=0.034)$ increased the catchability of gillnets and it seems that some other factor than merely the concentration of fish in small water volume affected the results. Poor oxygen condition in these lakes is linked to temperature which also can increase the probability of fish to be caught in gillnets, and temperature can be one factor that increased the catchability of fish during low oxygen conditions. Oxygen problems in the study site can also increase random variation in the gillnet data, because fish are more aggregated (concentrated to oxygenated habitats), which also increases the risk of gear saturation, and both factors will reduce the accuracy of CPUE estimate. Therefore, one should be aware of the oxygen problems in the monitored waters and take oxygen concentration into account when planning gillnet sampling and using CPUE as a density index.

In several previous studies, water temperature had been found to increase activity and thus the catchability in gillnets (Persson, 1986; Hansson and Rudstam, 1995; Tang and Boisclair, 1995; Linløkken and Haugen, 2006). This was supported by our results as well. However, according to the model results, the effect of water temperature was relatively low compared to other environmental factors (water colour and volume of oxygenated water) in these small forest lakes. It is reasonable that especially the volume of oxygenated water is crucial for fish in these lakes as it defines the available habitats and affects the competition and predation interactions (Rask, 1986). It should be pointed out however, that all the three factors water colour, temperature and oxygen conditions are confounded, which complicates the interpretation of the results. High water colour causes rapid warming of surface water in spring leading quickly to strong stratification, and eventually oxygen depletion in hypolimnion (Arvola et al., 1992). Changes in water clarity can change the timing and duration of fish activity peaks, which might affect the gillnet catch (Prchalová et al., 2010). In clear water, activity peaks are earlier in the morning and take place later in the evening, which might decrease gillnet CPUE in the case that the activity peaks don't fit in the $12 \mathrm{~h}$ set time used in this study.

In this study, the difference in the sex ratio between the density estimates and the gillnet catch was substantial. In perch, activitydifferences between the sexes are high during spawning time and growth period explaining the difference in the sex ratio. Also in many other fishes, sexes behave differently thus leading to different catchability (Horppila et al., 2011). Thus, sex ratio has to be taken into account when comparing the fish abundance estimates from different time periods. In this study, separate density estimates for males and females did not totally balance the sex ratio but the average female densities were $35 \%$ smaller than the average male densities. This might partly explain the observed higher catchability of perch in gillnets when the sex ratio in gillnet catch was less female-biased. Another explanation was the observed high male proportion when gillnet CPUE was high.

To conclude, gillnet CPUE can be used as a rough index of relative abundance in small humic lakes. It is recommended that oxygen profile, water transparency, temperature and fish sex distribution are recorded during gillnet monitoring, as these factors affect the catchability of gillnets.

\section{Acknowledgements}

We thank the field crew for their excellent and hard work. The Bergsrådet Bror Serlachius Foundation supported this work.

\section{References}

Argillier, C., Caussé, S., Gevrey, M., Pédron, S., De Bortoli, J., Brucet, S., Emmrich, M., Jeppesen, E., Lauridsen, T., Mehner, T., Olin, M., Rask, M., Volta, P., Winfield, I.J., Kelly, F., Krause, T., Palm, A., Holmgren, K., 2012. Development of a fish-based index to assess the eutrophication status of European lakes. Hydrobiologia 704, 193-211.

Arvola, L., Salonen, K., Kankaala, P., Lehtovaara, A., 1992. Vertical distributions of bacteria and algae in a steeply stratified humic lake under high grazing pressure from Daphnia longispina. Hydrobiologia 229, 253-269.

Bagenal, T.B., Tesch, F.W., 1978. Age and growth. In: Bagenal, T.B. (Ed.), Methods for the Assessment of Fish Production in Fresh Waters. Blackwell Scientific Publication, Oxford, pp. 101-136.

Borgstrøm, R., 1992. Effects of population density on gillnet catchability in four allopatric populations of brown trout (Salmo trutta). Can. J. Fish. Aquat. Sci. 49, 1539-1545.

Craig, J.F., 2000. Percid Fishes-Systematics, Ecology and Exploitation. Blackwell Science, Oxford

CEN, 2005. Water Quality Sampling of Fish with Multimesh Gillnets. European Committee for Standardization, Brussels (EN 14757).

Eloranta, P. (Ed.), 2004. Inland and Coastal Waters of Finland. University of Helsinki, Helsinki.

Enderlein, O., Appelberg, M., 1992. A comparison of pelagic gill-net, trawl and hydroacoustic data from two oligotrophic coregonid lakes. Pol. Arch. Hydrobiol. 39, 3-4.

Estlander, S., Horppila, J., Olin, M., Vinni, M., Lehtonen, H., Rask, M., Nurminen, L., 2012. Troubled by the humics-effects of water colour and interspecific competition on the feeding efficiency of planktivorous perch. Boreal Environ. Res. 17, 305-312.

Hamley, J.M., 1975. Review of gillnet selectivity. J. Fish. Res. Board Can. 32, 1943-1969.

Hansson, S., Rudstam, L.G., 1995. Gillnet catches as an estimate of fish abundance: a comparison between vertical gillnet catches and hydroacoustic abundances of Baltic Sea herring (Clupea harengus) and sprat (Sprattus sprattus). Can. J. Fish. Aquat. Sci. 52, 75-83.

Harley, S.J., Myers, R.A., Dunn, A., 2001. Is catch-per-unit effort proportional to abundance? Can. J. Fish. Aquat. Sci. 58, 1760-1772. 
Henderson, B.A., Trivedi, T., Collins, N., 2000. Annual cycle of energy allocation to growth and reproduction of yellow perch. J. Fish Biol. 57, 122-133.

Horppila, J., Olin, M., Vinni, M., Estlander, S., Nurminen, L., Rask, M., Ruuhijärvi, J., Lehtonen, H., 2010. Perch production in forest lakes: the contribution of abiotic and biotic factors. Ecol. Freshwater Fish 19, 257-266.

Horppila, J., Estlander, S., Olin, M., Pihlajamäki, J., Vinni, M., Nurminen, L., 2011. Gender-dependent effects of water quality and conspecific density on the feeding rate of fish-factors behind sexual growth dimorphism. Oikos 120, 855-861.

Kurkilahti, M., 1999. Nordic Multimesh Gillnet-Robust Gear for Sampling Fish Populations. Finnish Game and Fisheries Research Institute, Helsinki (Ph.D. Thesis).

Linløkken, A., Haugen, T.O., 2006. Density and temperature dependence of gill net catch per unit effort for perch, Perca fluviatilis, and roach, Rutilus rutilus. Fish. Manage. Ecol. 13, 261-269.

Minns, C.K., Hurley, D.A., 1988. Effects of net length and set time on fish catches in gill nets. North Am. J. Fish. Manage. 8, 216-223.

Olin, M., Kurkilahti, M., Peitola, P., Ruuhijärvi, J., 2004. The effects of fish accumulation on the catchability of multimesh gillnet. Fish. Res. 68, 135-147.

Olin, M., Malinen, T., Ruuhijärvi, J., 2009. Gillnet catch in estimating the density and structure of fish community-comparison of gillnet and trawl samples in a eutrophic lake. Fish. Res. 96, 88-94.

Olin, M., Vinni, M., Lehtonen, H., Rask, M., Ruuhijärvi, J., Saulamo, K., Ala-Opas, P., 2010. Environmental factors regulate the effects of roach Rutilus rutilus and pike Esox lucius on perch Perca fluviatilis populations in small boreal forest lakes. J. Fish Biol. 76, 1277-1293.

Olin, M., Rask, M., Ruuhijärvi, J., Tammi, J., 2013. Development and evaluation of the Finnish fish-based lake classification method. Hydrobiologia 713, 149-166.

Peltonen, H., Ruuhijärvi, J., Malinen, T., Horppila, J., 1999. Estimation of roach (Rutilus rutilus (L.)) and smelt (Osmerus eperlanus (L.)) stocks with virtual population analysis hydroacoustics and gillnet CPUE. Fish. Res. 44, 25-36.

Persson, L., 1986. Temperature-induced shift in foraging ability in two fish species, roach (Rutilus rutilus) and perch (Perca fluviatilis): implications for coexistence between poikilotherms. J. Anim. Ecol. 55, 829-839.
Prchalová, M., Mrkvička, T., Kubečka, J., Peterka, J., Čech, M., Milan, Muška, Michal, Kratochvíl, Mojmír, Vašek, 2010. Fish activity as determined by gillnet catch: a comparison of two reservoirs of different turbidity. Fish. Res. 102, 291-296.

Prchalová, M., Mrkvička, T., Peterka, J., Čech, M., Berec, L., Kubečka, J., 2011. A model of gillnet catch in relation to the catchable biomass, saturation, soak time and sampling period. Fish. Res. 107, 201-209.

Rask, M., 1986. The diet and diel feeding activity of perch, Perca fluviatilis L., in a small lake in southern Finland. Ann. Zool. Fennici 23, 49-56.

Rask, M., Sairanen, S., Vesala, S., Arvola, L., Estlander, S., Olin, M., 2014. Population dynamics and growth of perch in a small, humic lake over a 20-year period-importance of abiotic and biotic factors. Boreal Environ. Res. 19 (Suppl. A), 112-123.

Robson, D.S., Chapman, D.G., 1961. Catch curves and mortality rates. Trans. Am. Fish Soc. 90, 181-189.

Ruuhijärvi, J., Rask, M., Vesala, S., Westermark, A., Olin, M., Keskitalo, J., Lehtovaara A., 2010. Recovery of the fish community and changes in the lower trophic levels in a eutrophic lake after a winter kill of fish. Hydrobiologia 646, 145-158.

Salonen, K., Arvola, L., Rask, M., 1984. Autumnal and vernal circulation of small forest lakes in Southern Finland. Verh. Internat. Ver. Limnol. 22, 103-107.

Seber, G.A.F., 1982. The Estimation of Animal Abundance and Related Parameters, second ed. The Athenaeum Press Ltd., London, United Kingdom, pp. 654 pp.

Sutela, T., Rask, M., Vehanen, T., Westermark, A., 2008. Comparison of electrofishing and NORDIC gillnets for sampling littoral fish in boreal lakes. Lakes Reservoirs Res. Manage. 2008 (13), 215-220.

Tang, M., Boisclair, D., 1995. Relationship between respiration rate of juvenile brook trout (Salvelinus fontinalis), water temperature, and swimming characteristics. Can. J. Fish. Aquat. Sci. 52, 2138-2145.

Thorpe, J.E., 1977. Synopsis of biological data on the perch, Perca fluviatilis Linnaeus, 1758 and Perca flavescens Mitchill, 1804. In: FAO Fisheries Synopsis 113, p. 138

Tonn, W., Magnuson, J., Rask, M., Toivonen, J., 1990. Intercontinental comparison of small-lake fish assemblages: the balance between local and regional processes. Am. Nat. 136, 345-375. 